\title{
Phytotoxic effect of Pinus Elliottii extracts on invasive plants from agricultural cultivation systems
}

Among the factors that lead to low rural productivity, weeds are responsible for $34 \%$ of the reductions in agricultural incomes. The increase and uncontrolled use of agrochemicals such as glyphosate is increasingly requiring less-harmful alternatives to the human health and environment that ensure weed control and food security. This study, therefore, investigated a property called allelopathy encountered in the pine species Pinus elliottii, in order to evaluate the bioherbicidal potential of its allelopathic effect on invasive plants from pre- and postemergent agricultural cultivation systems. Initially, the aqueous extracts obtained from Pinus elliottii needles were diluted in different concentrations and models according to the test to be performed. To simulate a post-emergent system, the extracts were applied to young individuals of Conyza bonariensis and Cyperus rotundus, both species of weeds. Subsequently, samples of the roots and aerial parts were collected and subjected to moisture and metal analysis. Acid digestion occurred in a microwave oven with the samples from each set previously dried to measure the amount of sodium $(\mathrm{Na})$ and potassium $(\mathrm{K})$ by flame photometry. With regards to the pre-emergent system, the interference of Pinus elliottii in germination and seedling formation factors of the Bidens pilosa species was analysed. In addition, the extracts were subjected to the analysis of organic compounds and acute ecotoxicity through tests with Artemia salina nauplii. The post-emergent test demonstrated a similarity in the phytotoxic effect of Pinus elliottii and the reference herbicide glyphosate, by reducing the humidity of the roots and aerial parts, which increases $\mathrm{Na}$ and decreases K contents, suggesting a metabolic imbalance in the plant that causes its death. The pre-emergent test revealed that the $16 \%$ extract $(\mathrm{m} / \mathrm{v}$ ) caused $100 \%$ inhibition in Bidens pilosa germination and the $8 \%$ extract demonstrated statistical significance by interfering in the delay and formation of seedlings and germination. Re arding ecotoxicity, Pinus elliottii indicated $1 C 50$ equals to $2000 \mathrm{ppm}$ of the $16 \%$ extract, falling within the limit of toxicity that determines $1 C 50<1000$ ppm for toxic substances. Therefore, Pinus elliottii extracts revealed efficiency in both pre- and post-emergent systems and guaranteed toxicity within approved environmental standards, which serves as evidence of its promising phytotoxic potential and use as a bioherbicide.

Keywords: Allelopathy; Bioherbicide; Ecotoxicity; Glyphosate.

\section{Efeito fitotóxico de extratos de Pinus Elliottii sobre plantas invasoras de sistemas de cultivo agrícola}

Dentre os fatores que acarretam a baixa produtividade rural, ervas daninhas são responsáveis por $34 \%$ das reduções nos rendimentos agrícolas. Devido ao aumento e descontrole do us de agroquímicos como o glifosato, requer-se, cada vez mais, alternativas menos prejudiciais à saúde humana e ao ambiente e que assegurem o controle de ervas e a segurança alimentar. Em vista disso, este estudo investigou uma propriedade denominada de a alelopático sobre plantas invasoras de sistemas de cultivo agrícola pré e pós-emergentes. Inicialmente, os extratos aquosos obtidos a partir dos ramos de Pinus elliottii foram diluídos em diferentes concentrações e modelos de acordo com o teste a ser realizado. Para simular um sistema pós-emergente, os extratos foram aplicados sobre indivíduos jovens de Conyza bonariensis e Cyperus rotundus, ambas as espécies de ervas. Posteriormente, amostras das raízes e partes aéreas das ervas foram coletadas e submetidas a análises de umidade e metais. A digestão ácida ocorreu em um forno micro-ondas com as amostras de cada conjunto previamente desidratadas para a medição dos teores de sódio ( $\mathrm{Na}$ ) e potássio (K) através de fotometria de chama. Em relação ao sistema pré-emergente, analisou-se a interferência do Pinus elliottii em fatores de germinação e formação de plântulas da espécie Bidens pilosa. Ademais, os extratos foram submetidos a análises de compostos orgânicos e ecotoxicidade aguda através de testes com nauplios de Artemia salina. O teste pós-emergente demonstrou uma similaridade entre o efeito fitotóxico do Pinus elliottii e do herbicida referência, o glifosato, através da redução da umidade das raízes e partes aéreas das amostras, o que acarreta o aumento de $\mathrm{Na}$ e diminuição de K na planta, sugerindo-se um desequilíbrio metabólico que ocasiona e morte vegetal. $\mathrm{O}$ teste pré-emergente revelou que o extrato a $16 \%$ ( $\mathrm{m} / \mathrm{v}$ ) causou $100 \%$ de inibiç̃̃o na germinação de Bidens pilosa e 0 extrato a $8 \%$ foi suficiente para demonstrar significância estatistica ao interferir no atraso e formação de plântulas e germin) Cão. Com

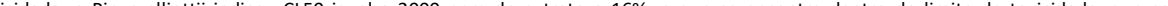
substâncias tóxicas. Desta forma, os extratos do Pinus elliottii revelaram eficiência tanto em sistemas pré quanto pós-emergentes e garantiram toxicidade dentro de diretrizes ambientais regulamentadas, evidenciando-se, portanto, seu promissor potencial fitotóxico e uso como bioherbicida.

Palavras-chave: Alelopatia; Bioherbicida; Ecotoxicidade; Glifosato.

Peterson Haas (iD)

Universidade do Vale do Taquari, Brasil http://lattes.cnpq.br/7500747057637325 http://orcid.org/0000-0001-8106-8012

peterson.haas@gmail.com

\section{Daniel Kuhn}

Universidade do Vale do Taquari, Brasil

http://lattes.cnpq.br/2164018760361843

danielkuhn@universo.univates.br

\section{Sabrina Grando Cordeiro (id}

Universidade do Vale do Taquari, Brasil

http://lattes.cnpq.br/2337098282279202

https://orcid.org/0000-0003-1725-6662

sabrina.cordeiro@univates.br

\section{Ytan Andreine Schweizer \\ Universidade do Vale do Taquari, Brasil \\ http://lattes.cnpq.br/7243347940977880 \\ ytan.schweizer@universo.univates.br}

\section{Bruna Costa}

Universidade do Vale do Taquari, Brasil

bruna.costa@universo.univates.br

\section{Lucélia Hoehne (ic)}

Universidade do Vale do Taquari, Brasil

http://lattes.cnpq.br/1088266827926373

https://orcid.org/0000-0002-3221-7007

luceliah@univates.br

\section{Referencing this:}

HAAS, P.; KUHN, D.; CORDEIRO, S. G.; SCHWEIZER, Y. A.; COSTA, B. HOEHNE, L.. Phytotoxic effect of Pinus Elliottii extracts on invasive plants from agricultural cultivation systems. Revista Ibero Americana de Ciências Ambientais, v.12, n.5, p.121-131, 2021. DOI: http://doi.org/10.6008/CBPC2179-6858.2021.005.0011 


\section{INTRODUCTION}

Due to their adaptation and accelerated dispersion potential, invasive plants lead to a reduction of $34 \%$ in the agricultural yields (PANNACCl et al., 2017; JABRAN et al., 2015), since they compete with crops for environmental resources, such as water, luminosity, nutrients and space (CIRILLO et al., 2018; RIZZARDI et al., 2001). Manual and mechanical methods to remove invasive plants from agriculture and herbicide application have been the most effective methods to perform weed control (GRIEPENTROG et al., 2010). However, the most commercialized herbicides worldwide are glyphosate-based [ $\mathrm{N}$ - (phosphonomethyl) glycine], a toxic compound to human health and the ecosystem (TORRETA et al., 2018; ANNETT et al., 2014; YAMADA et al., 2007). Glyphosate's mechanism of action allows the accumulation of the compound in the meristematic regions of invasive plants, inhibiting the enzyme 5-enolpyruvylshikimate-3 phosphate synthase (EPSPs) that is responsible for the synthesis of essential amino acids, ultimately leading to the death of the plants (HAAS et al., 2018).

Although the mechanism of action of the compound does not directly affect the human organism, there are evidences of its environmental effects. Since certain cultures are increasingly becoming more tolerant and resistant to glyphosate, applications with high dosages of the compound on agricultural productions are necessary to ensure its efficiency, which result in soil and groundwater contaminations. (ABBAS et al., 2018; VAN BRUGGEN et al., 2018; XU et al., 2019). Additionally, crops retain high amounts of the agrochemical, and its ingestion by humans accumulates the compound in the organism with a level of toxicity that exceeds the limit established by legislation and safety protocols (AMARANTE JUNIOR et al., 2002; TEIXEIRA et al., 2019). In this way, the use of sustainable alternatives for weed control is of utmost importance, which implies lower toxicity rates compared to current herbicides.

According to this, allelopathy is a mechanism of competition developed by many plant communities, which consists of the interference in the development of another plant through the release of chemical inhibitors in the soil (PIRES et al., 2011). Therefore, alternative methods for agricultural management such as allelopathy have been studied, as the allelopathic potential of crops and plant extracts may contribute to weed suppression in plantations. According to the study conducted by Jabran et al. (2015), which evaluated the allelopathy of soybean and corn, this property occurs in the roots of these vegetables, as the culture releases substances in the soil that inhibit the development of other crops and, essentially, weeds.

Other studies have also indicated the use of allelopathy for weed control through the application of plant extracts with such property. Sartor et al. (2015) evaluated the effect of fresh and dry Pinus taeda needles extracts over Bidens pilosa, revealing the reduction of plant germination, as well as the determination of the compound of Pinus elliottii allelopathic effect, evidencing the presence of groups of terpenes. Additionally, Azevedo et al. (2007) studied the allelopathic effect of Eucalyptus citriodora and Pinus elliottii extract over the germination of Lactuca sativa L. (lettuce) plantations, resulting in the high inhibitory and non-selective potential of the extracts over the crop. Therefore, allelopathy can be an alternative for weed proliferation management, since its natural allelochemicals can be effective, 
economically viable, and less-toxic to the environment and human health (IQBAL et al., 2019; JABRAN et al., 2015).

In this way, it was verified the abundance of the species of Pinus elliottii in the southern region of Brazil, whose allelopathic property was studied to evaluate its bioherbicidal potential. The main forms of release of allelochemicals in the environment were found to arise from leaf leaching, root transpiration, decomposition of plant residues, and volatilization. Similarly, this process is linked to the production of its oleoresin, in which the volatile portion, represented by mono and sesquiterpenes, is released due to internal and external stimuli, such as seasonality, in which hot seasons accentuate the volatilization of these allelochemicals (CORRÊA et al., 2017; SARTOR et al., 2015).

Moreover, the highest concentrations of these classes of terpenes are in their aerial parts, which are not economically exploited, since the economic exploration of Pinus elliottii comes essentially from its wood and resin. Therefore, the use of its leaves for bioherbicidal use would also ensure a sustainable reuse of these parts rather than improperly disposing them in the soil.

The current study evaluated the bioherbicidal potential and the phytotoxic effect of aqueous extracts of Pinus elliottii needles on invasive plants from pre- and post-emergent agricultural cultivation systems.

\section{METHODOLOGY}

\section{Extract Preparation}

Slash needles of Pinus elliottii were collected in a pine plantation in the city of Lajeado/RS, Brazil, during the summer season of 2019. They were washed in water, weighed, added in recipients with determined amount of distilled water and then shredded. Extracts of three different concentrations were performed according to the methodology of Azevedo et al. (2007), who established studies with 5\% (m/v) extracts to inhibit the development of Lactuca sativa (lettuce). Besides the production of the $5 \%$ extract, $2.5 \%$ and $7.5 \%$ extracts were also made. After $24 \mathrm{~h}$, the extracts were filtered through cotton layers and, subsequently, vacuum filtered, using a vacuum filtering flash coupled to a vacuum pump, resulting in green solutions with color variation according to the aqueous dilution. The solutions were applied immediately to the plant samples after the completion of the process. Regarding the pre-emergent test with Bidens pilosa seeds, the same methodology was applied, but the extracts had the following concentrations: $1,2,4,8$, and $16 \%$.

In addition, the extracts for the ecotoxicity test were prepared according to NBR 12713 (ABNT, 2016). The $16 \%$ extract was inserted in a rotary evaporator at $40 \pm 2$ oC for the evaporation of its liquid part. The pasty residue was removed with a yield of $1.3 \%$. The residue was resuspended at concentrations of $500,800,1100,1400,1700$, and 2000 ppm.

\section{Plant Samples Preparation}

Seeds of the two species of weed were harvested in plantations whose soils were not subjected to 
external factors, such as herbicide application, in the city of Lajeado/RS, Brazil, during the summer season. Samples were placed in a greenhouse under controlled temperature and humidity. Individuals of Conyza bonariensis about $15 \mathrm{~cm}$ long were replanted in containers with selected nutrient-rich soil. For Cyperus rotundus samples, their tubers with high generative power were used and arranged in equal containers and soil. All samples were acclimated for two weeks in the greenhouse before receiving the application of each treatment.

\section{Interference in Post-Emergent System}

Twenty samples of each species were selected for each of the five treatments of the experiment and each test was performed in triplicates $(n=3)$. In the first set of samples, glyphosate at $0.48 \%$ was used as the reference herbicide. In the second, third and fourth sets, extracts at $2.5 \%, 5 \%$, and $7.5 \%$, respectively, were applied on the samples. The fifth set was the control group, in which plants grew without the application of inhibitors for comparative purposes. This experiment occurred for 10 weeks, and every day the samples received the same amounts of water and were under the same levels of humidity and temperature. In addition, there were three biweekly applications of the extracts on the samples, while there was a single application of glyphosate on the samples. Through this post-emergent experiment, the effectiveness of Pinus elliottii's allelopathy was compared to the inhibition performed by glyphosate. Biomass and Humidity

After visual analysis of the results obtained from each set in the post-emergent experiment, the samples were collected, the aerial parts and roots were separated and measured, and the fresh biomass was weighted from both parts. Subsequently, the samples were dried in an oven at $105 \stackrel{\circ}{C}$ for 4 hours, then the resulting biomass was weighted and the variation of the percentage of water in the fresh and dry samples was measured.

\section{Acid Digestion}

Acid digestion occurred with dry samples, according to the methodology adapted from Yang et al. (2013). Six milliliters of nitric acid were added on $0.15 \mathrm{~g}$ of dehydrated samples, with the solution inserted in a microwave oven at $180{ }^{\circ} \mathrm{C}$ for $15 \mathrm{~min}$. The resulting solution was then filtered to remove the silica formed at the bottom of the recipient, collected in $10 \mathrm{~mL}$ volumetric flasks, and made up to volume with deionized water.

\section{$\mathrm{Na}$ and $\mathrm{K}$ Quantitation}

Digestion allowed the degradation of organic matter and the maintenance of certain macronutrients in the solution. Potassium $(\mathrm{K})$ and Sodium $(\mathrm{Na})$ were quantified by flame photometry according to the methodology adopted by Almeida et al. (2002). All analyses were performed in triplicate and conducted at Chemistry laboratories at Vale do Taquari University - Univates, in Lajeado/RS, Brazil. 


\section{Interference in Germination and Seedling Formation}

According to Sartor et al. (2015), plants with a high allelopathic potential may be able to prevent the germination of other species in their surroundings. Therefore, in vitro tests were carried out to analyze the effects of germination and seedling formation of weeds under the application of the Pinus elliottii extract.

Therefore, seeds of Bidens pilosa were used, since several studies have already indicated its tolerance to glyphosate, its abundance in the region where the study was conducted, and its accelerated germination rate. Using the methodology of (VIEIRA et al., 2018), seeds were washed, disinfected in sodium hypochlorite solution $(2.0-2.5 \% \mathrm{v} / \mathrm{v})$ and then passed through a triple wash in autoclaved and distilled water.

Petri dishes with dimensions of $305 \times 205 \times 60$ mm (length, width and height, respectively) were autoclaved and disinfected with $96 \%$ alcohol, and three specific paper for seed germination served as the germinative medium, along with $8 \mathrm{~mL}$ of the extract at 1, 2, 4, 8, and 16\%. Additionally, the treatment $0 \%$ served as the control group and included $8 \mathrm{~mL}$ of water only. Twenty seeds were placed in each plate with four replicates per treatment $(n=4)$, totaling 24 plates and 6 treatments. The plates were randomly arranged in a germination house with 16 hours of photoperiod, light intensity of 466 Lux (fluorescent lamp) and at 25 으. The number of germinated seeds and seedling formation was monitored daily for 30 days through visual inspection by pairs. Through the experiment, it was observed the percentage of germinated seeds (PG), germination speed index (IVG), percentage of seedling formation (PPC), seedling formation speed index (IVP) and the ratio between formed seedlings and germinated seeds (RPFSG), in percentage. Ecotoxicity

The present test was carried out to evaluate the Lethal Concentration of the aqueous extracts of Pinus elliottii for $50 \%$ of the test organisms ( $\left(\mathrm{C}_{50}\right)$, using the microcrustacean Artemia salina. According to the NBR 12713 (ABNT, 2016) and Meyer et al. (1982), cysts of the species were induced to hatch for 48 hours in aqueous solution at a concentration of $2.7 \%$ of sea salt, with constant aeration and temperature of 27 으. Adult specimens of approximately $0.6 \mathrm{~mm}$ were isolated and ten nauplii were placed in each treatment.

Tests were performed in triplicates, using 24-well plates (Kasvi) of $16.25 \times 16.25 \times 17.3 \mathrm{~mm}$. For the negative control of toxicity, $3 \mathrm{~mL}$ of $1.5 \%$ saline solution was applied to each well. For the positive control of toxicity, $2 \mathrm{ml}$ of potassium dichromate concentration and $1 \mathrm{ml}$ of saline solution were applied in each plate. The potassium dichromate solution was prepared by diluting it to $1 \mathrm{mg} / \mathrm{mL}$ and then used in the following volumes: $800,400,200,100,50$ and $25 \mu \mathrm{L}$.

Pinus elliottii solutions were obtained by diluting the rotative evaporated solid extract in the concentrations of 2000, 1700, 1400, 1100, 800 and 500 ppm. The LC 50 was evaluated 24 and 48 hours after the experiment, with the count of living and dead organisms. Concentrations of the extract with $\mathrm{LC}_{50}<1000$ $\mu \mathrm{g} / \mathrm{mL}$ are considered toxic (MEYER et al., 1982). Likewise, the test is valid if samples with $1.5 \%$ saline have a lethality less than or equal to $10 \%$ (EL FELS et al., 2016), if samples with potassium dichromate have LC 50 
between 30 and $50 \mu \mathrm{g} / \mathrm{mL}$ after 24 hours (SVENSSON et al., 2005) and if there is a correlation for the determination of the $L C_{50}$ of the extract concentrations with $\mathrm{R}^{2}>0.9$ (MEYER et al., 1982).

\section{Statistical Analysis}

The statistical analysis of the data took place through Analysis of Variance - ANOVA and regression of the parameters of growth and germination of the samples of Bidens pilosa and lethality test with Artemia salina, through the InfoStat software.

\section{RESULTS AND DISCUSSION}

\section{Leaf Inhibition Analysis}

In vivo experiments with Conyza bonariensis samples indicated partial efficiency of the $7.5 \%$ extract of Pinus elliottii, which resulted in $50 \%$ of the samples to die off and the ends of the resulting samples' leaves to dry out. The $5 \%$ extract showed only leaf dryness, with no dead samples. The $2.5 \%$ extract evidenced no adverse effects on the samples. In addition, the control set showed no death nor leaves deformities, indicating favorable conditions for plant development.

Regarding the Cyperus rotundus samples, the $7.5 \%$ extract did not inhibit or reveal visual leaf deformation. Additionally, samples under the application of glyphosate had $20 \%$ of leaf dryness and no death. These results are consistent with studies performed by Assis et al. (2018), whereby the authors did not significantly and statistically inhibit the development and reproduction of Cyperus rotundus samples through the application of four concentrations of glyphosate $\left(1080,1440,1800\right.$, and $\left.2160 \mathrm{~g}^{\mathrm{kg}} \mathrm{g}^{-1}\right)$. Since the commercialized agrochemical did not demonstrate high levels of efficiency on samples, the high tolerance of the species to inhibitors with such mechanism of action could be verified. According to Kadir et al. (2000), the reproduction of Cyperus rotundus via tubers and rhizomes, its efficient ability to convert carbon dioxide to carbohydrate and its tolerance to moisture variation and high-temperature soils justifies its tolerance to certain agrochemicals.

\section{Moisture Evaluation}

By measuring the weight of the aerial parts and roots before and after dehydration, it was possible to evaluate the change in the humidity percentage of Conyza bonariensis and Cyperus rotundus samples, verifying the root moisture analysis in Table 1.

Table 1: Values of wet and dry biomass and percentage of humidity in the roots of the samples.
C. bonariensis control $C$. rotundus control
C. bonariensis $7,5 \%$ extract
C. rotundus $7,5 \%$ extract
C. rotundus glyphosate

\begin{tabular}{llllll}
\hline wet biomass (g) & 3.55 & 10.23 & 1.15 & 7.20 & 9.85 \\
dry biomass (g) & 0.61 & 3.33 & 0.31 & 1.61 & 2.47 \\
\hline Moisture (\%) & 82.8 & 67.4 & 73.0 & 77.6 & 74.9 \\
\hline
\end{tabular}

*Results expressed as average $(n=3)$ 
The humidity percentage of $82.8 \%$ and $67.4 \%$ for Conyza bonariensis and Cyperus rotundus, respectively, in the control sets, refers to the base percentage in these two set of samples. Therefore, with regards to Conyza bonariensis, the highest concentration of the Pinus eliottii extract presented lower humidity percentage $(73.0 \%)$ in the dry samples compared to the control group, indicating the interference of Pinus elliottii in the plant's water absorption system. Such interference was observed visually in Conyza bonariensis root samples under glyphosate, but no data could be collected regarding the moisture variation of these fresh and dry samples, as the roots were substantially dehydrated and degraded due to the high potential of the agrochemical's mechanism of action to impair water absorption. (KRUSE et al., 2000). Regarding the Cyperus rotundus samples, the values of biomass between the fresh and dry samples were similar, because both the mechanism of action of glyphosate and the concentrations of Pinus elliottii extracts showed low performance in this test.

The biomass analysis of the aerial parts of Conyza bonariensis and Cyperus rotundus samples demonstrated no interference of the extracts. This result suggests that the interference of the Pinus elliottii occurred only in the moisture of roots and not of aerial parts as roots are the first contacts plants have with the soil. Therefore, since plants use their root system to absorb nutrients and water from the soil, significant interference on water absorption of the roots were expected to be more significative than of the aerial parts, but the latter may be affected posteriorly depending on the characteristics of the plant species. This same behavior was observed by Paulus et al. (2012), who evaluated the growth, water consumption, and mineral composition of lettuce developed in hydroponics with saline waters. Additionally, with regards to the moisture variation in roots, it is suggested that Pinus elliottii affects a specific physiological characteristic of plants that involve the absorption of certain mineral salts, which would lead to levels of water imbalance in plants (SERRA et al., 2011).

\section{Macronutrient Concentration in Samples}

Quantitative analyses of the presence of macronutrients such as $\mathrm{Na}$ and $\mathrm{K}$ in the plants were necessary to verify the association between Pinus elliottii extracts and the absorption of these macronutrients by the weeds, as the extracts had previously demonstrated interference in the water regulation system of Conyza bonariensis samples. Tables 2 and 3 indicate the concentration of these compounds in Conyza bonariensis and Cyperus rotundus samples, respectively.

Table 2: Results of the quantitative analysis of $\mathrm{Na}$ and $\mathrm{K}$ from the aerial part of Conyza bonariensis.

\begin{tabular}{lcc}
\hline Treatment & \multicolumn{2}{c}{ Concentration (mg/g)* } \\
\cline { 2 - 3 } & $\mathrm{Na}$ & $\mathrm{K}$ \\
\hline Control & $4.69 \pm 0.19$ & $40.68 \pm 0.14$ \\
Aqueous Extract (7.5\%) & $6.08 \pm 0.74$ & $35.81 \pm 1.08$ \\
Glyphosate & $7.33 \pm 0.60$ & $33.88 \pm 2.69$ \\
\hline
\end{tabular}

\footnotetext{
*Results expressed as average \pm S.D. $(n=3)$
} 
Table 3: Results of the quantitative analysis of $\mathrm{Na}$ and $\mathrm{K}$ from the aerial part of Cyperus rotundus.

\begin{tabular}{lcc}
\hline \multirow{2}{*}{ Treatment } & \multicolumn{2}{c}{ Concentration (mg/g)* } \\
\cline { 2 - 3 } & $\mathrm{Na}$ & $\mathrm{K}$ \\
\hline Control & $5.40 \pm 0.02$ & $33.11 \pm 0.09$ \\
Aqueous Extract (7.5\%) & $5.92 \pm 0.08$ & $38.14 \pm 0.33$ \\
Glyphoste & $0.58 \pm 0.00$ & $2.76 \pm 0.04$ \\
\hline
\end{tabular}

*Results expressed as average \pm S.D. $(n=3)$

Regarding Conyza bonariensis samples, both the $7.5 \%$ extract and glyphosate revealed an increase in Na concentration compared to the control group. Moreover, both increases are statistically equal, since they correspond to the same standard deviation and average margins. Regarding $\mathrm{K}$ concentrations, opposite results were discovered, as both the highest concentration of the extract and glyphosate decreased the levels of this compound in the samples.

The similar effects provided by the 7.5\% extract and glyphosate indicate that the increase of $\mathrm{Na}$ and decrease of $\mathrm{K}$ concentrations in the samples lead to a deregulation in the sodium-potassium system, which mainly impairs the absorption of $\mathrm{K}$. Such effect causes an imbalance in the system, causing the death of the plant (YAMADA et al., 2007).

Since both Pinus elliottii extract and glyphosate did not caused significant inhibitory effects nor variations in moisture analysis in Cyperus rotundus samples, such alterations were also not revealed in the macronutrient analysis, since the $\mathrm{Na}$ and $\mathrm{K}$ imbalance was not clearly observed from the same way as in Conyza bonariensis.

\section{Effects on seed germination}

In vitro tests with Bidens pilosa aimed to evaluate the phytotoxicity of Pinus elliottii extracts in the germination and initial development of samples submitted to six treatments. Through the results and statistical analysis present in table 4, it was observed that until the concentration of $4 \%$ there was no statistical difference in the percentage of germinated seeds (PG) and percentage of seedling formation (PPC) for $p<0,05$. However, there was an expressive difference for concentrations of $8 \%$ and $16 \%$, with the latter indicating an inhibitory efficiency of $100 \%$.

Table 4: Results of the statistical analysis of factors that interfere in the germination of Bidens pilosa.

\begin{tabular}{lccccc}
\hline Treatment & PG & IVG & PPC & IVP & RPFSG \\
\hline $\mathbf{0 \%}$ & $88.75 \pm 10.31 \mathrm{c}$ & $7.16 \pm 0.88 \mathrm{~d}$ & $85.00 \pm 12.25 \mathrm{c}$ & $0.09 \pm 0.01 \mathrm{~d}$ & $95.83 \pm 8.33 \mathrm{c}$ \\
$\mathbf{1 \%}$ & $88.75 \pm 4.79 \mathrm{c}$ & $5.12 \pm 0.49 \mathrm{c}$ & $83.75 \pm 4.79 \mathrm{c}$ & $0.08 \pm 0.003 \mathrm{~cd}$ & $94.43 \pm 4.31 \mathrm{bc}$ \\
$\mathbf{2 \%}$ & $90.00 \pm 8.16 \mathrm{c}$ & $5.52 \pm 1.15 \mathrm{~cd}$ & $85.00 \pm 7.07 \mathrm{c}$ & $0.07 \pm 0.01 \mathrm{c}$ & $94.58 \pm 4.54 \mathrm{bc}$ \\
$\mathbf{4 \%}$ & $82.50 \pm 8.66 \mathrm{c}$ & $4.91 \pm 0.97 \mathrm{bc}$ & $75.00 \pm 7.07 \mathrm{c}$ & $0.07 \pm 0.01 \mathrm{c}$ & $91.11 \pm 6.02 \mathrm{bc}$ \\
$\mathbf{8 \%}$ & $58.75 \pm 13.77 \mathrm{~b}$ & $3.21 \pm 0.94 \mathrm{~b}$ & $37.50 \pm 23.27 \mathrm{~b}$ & $0.05 \pm 0.01 \mathrm{~b}$ & $60.85 \pm 35.74 \mathrm{~b}$ \\
$\mathbf{1 6 \%}$ & $0.00 \pm 0.00 \mathrm{a}$ & $0.00 \pm 0.00 \mathrm{a}$ & $0.00 \pm 0.00 \mathrm{a}$ & $0.00 \pm 0.00 \mathrm{a}$ & $0.00 \pm 0.00 \mathrm{a}$
\end{tabular}

*Results expressed as average \pm S.D. $(n=4)$. Averages followed by the same letter do not differ by Tukey's test, at a 
level of 5\% probability. Legend: PG: Germination Percentage, IVG: Germination Speed Index, PPC: Seedling Formation Percentage, IVP: Seedling Formation Speed Index, RPFSG: Ratio between Formed Seedlings and Germinated Seeds.

In addition to the direct inhibitory response presented in germination and seedling formation in most of the samples, there was also a delay in the initial time of germination and seedling formation in the remaining samples that had not been inhibited, which was indicated through the analysis of IVG and IVP, respectively. Therefore, it was observed that the delay in the germination and formation of seedlings was again statistically significant in the concentration of $8 \%$, while that of $16 \%$ did not present these parameters since the high efficiency of this concentration left no sample to be analyzed.

Through the relationship between germinated seeds and formed seedlings (RPFSG), it was discovered that for all seeds that can germinate under the treatments, as the extract concentration increases their seedling formation potential decreases. This factor indicates that although there may have germination under high concentrations of Pinus elliottii, the plants will not fully complete their development as their seedling stage have been impaired.

\section{Ecotoxicity with Artemia salina}

The results of the toxicity tests with the Pinus elliottii extracts on Artemia salina nauplii can be verified in Figure 1. The results were validated, since the lethality rate of the tests with $1.5 \%$ saline was $0 \%$ and the samples with potassium dichromate indicated $\mathrm{LC}_{50}$ equal to $50 \mu \mathrm{g} / \mathrm{mL}$.

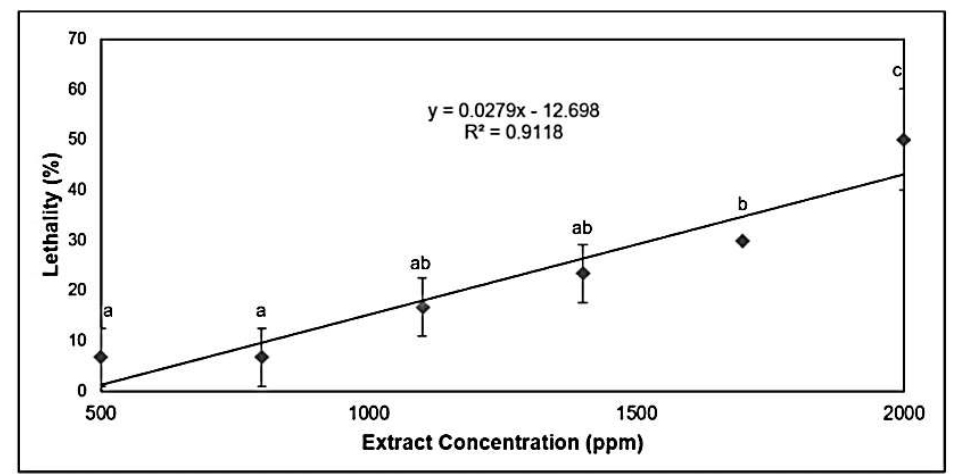

Figure 1: Lethality (\%) of Artemia salina in the concentrations of Pinus elliottii extracts (ppm).

Pinus elliottii extracts indicated low toxicity values in the tests performed. Through linear regression of the data, it was possible to determine that the $\mathrm{LC}_{50}$ is equivalent to $2247 \mathrm{ppm}$, which is not considered toxic to Artemia salina, whose toxic concentrations would correspond to $\mathrm{LC}_{50}<1000 \mathrm{ppm}$.

\section{CONCLUSION}

Through the moisture analysis of the samples performed, it was discovered that Pinus elliottii extracts decrease the humidity of Conyza bonariensis roots. Once the level of moisture decays, the imbalance in the absorption of salts in the plant occurs, resulting in the increase of $\mathrm{Na}$ and decrease of $\mathrm{K}$. The variation of these compounds suggests a metabolic imbalance in the plant, leading to its death.

Promising results were also observed in Bidens pilosa regarding the germination of seeds and seedling formation, both primary stages of plant development. All parameters showed significant results, 
indicating that the extracts inhibited seed germination and seedling formation or delayed them. In addition, the $16 \%$ extract inhibited $100 \%$ of the samples. Moreover, although the $8 \%$ extract demonstrated inhibition in about $59 \%$ of the samples, it presented significative results in delaying or inhibiting the seedling formation of the samples that germinated, impairing the complete development of the plant. This result is especially relevant because many agrochemicals such as glyphosate are inefficient regarding pre-emergent systems, since most of them are unable to act in both pre- and post-emergent systems as Pinus elliottii extracts does.

Moreover, the extracts evidenced low toxicity regarding Artemia salina, with $\mathrm{LC}_{50}=2247 \mathrm{ppm}$. Through the similarity between the mechanism of action of Pinus elliottii extracts and glyphosate, the significant results in the pre-emergent tests with seed germination and seedling formation and its low toxicity, it is possible to determine the prominent efficiency and viability of Pinus elliottii's phytotoxic effect and potential use as a bioherbicide.

\section{REFERENCES}

ABBAS, T.; ZAHIR, A. Z.; NAVEED, M.; KREMER, R. J. Limitations of Existing Weed Control Practices Necessitate Development of Alternative Techniques Based on Biological Approaches. Advances in Agronomy, v.147, p.239-280, 2018. DOI: https://doi.org/10.1016/bs.agron.2017.10.005

ABNT. Associação Brasileira De Normas Técnicas. NBR 12713: ecotoxicologia aquática - Toxicidade aguda Método de ensaio com Daphnia spp (Crustacea, Cladocera) Aquatic, 2016.

ALMEIDA, M. M. B.; LOPES, M. F. G.; NOGUEIRA, C. M. D.; MAGALHÃES, C. E. C.; MORAIS, N. M. T.. Determinação de nutrientes minerais em plantas medicinais. Ciência e Tecnologia de Alimentos, v.22, n.1, p.94-97, 2002. DOI: http://dx.doi.org/10.1590/S0101-20612002000100017

ANNETT, R.; HABIBI, H. R.; HONTELA, A.. Impact of glyphosate and glyphosate-based herbicides on the freshwater environment. Journal of Applied Toxicology, v.34, n.5, p.458-479, 2014. DOI: https://doi.org/10.1002/jat.2997

ASSIS, M.; SANTANA, M.; VAN KEMPEN, J.; MELLO, I.; AMARAL, D.. Doses de Glyphosate e Uso de Adjuvantes no Controle de Plantas Daninhas. In: SEMINÁRIO DE PESQUISA E INOVAÇÃO TECNOLÓGICA. Anais. Uberaba, 2018.

AZEVEDO, V. K.; BRAGA, T. V. S.; GOI, S. R.. Citriodora E Pinus Eliotti Sobre a Germinação De Lactuca sativa L. (alface). In: SOCIEDADE DE ECOLOGIA DO BRASIL. Anais. Caxambu, 2007.

CIRILLO, V.; MASIN, R.; MAGGIO, A.; ZANIN, G.. Crop-weed interactions in saline environments. European Journal of Agronomy, v.99, p.51-61, 2018. DOI: https://doi.org/10.1016/j.eja.2018.06.009

CORRÊA, K. C. S. R.; HALMENSCHLAGER, G.; SCHWAMBACH, J.; COSTA, F.; MEZZOMO-TREVIZAN, E.; FETT-NETO, A. G. Dual allelopathic effects of subtropical slash pine (Pinus elliottii Engelm.) needles: Leads for using a large biomass reservoir. Industrial Crops and Products, v.108, p.113-120, 2017. DOI: https://doi.org/10.1016/j.indcrop.2017.06.019
DE AMARANTE JUNIOR, O. P.; DOS SANTOS, T. C. R.; BRITO, N. M.; RIBEIRO, M. L.. Glifosato: propriedades, toxicidade, usos e legislação. Quimica Nova, v.25, n.4, p.589-593, 2002. DOI: http://dx.doi.org/10.1590/S0100-40422002000400014

EL FELS, L.; HAFIDI, M.; OUHDOUCH, Y.. Artemia salina as a new index for assessment of acute cytotoxicity during cocomposting of sewage sludge and lignocellulose waste. Waste Management, v.50, p.194-200, 2016. DOI: https://doi.org/10.1016/j.wasman.2016.02.002

GRIEPENTROG, H. W.; DEDOUSIS, A. P.. Mechanical Weed Control. Mechanical Weed Control, v.20, p.171-179, 2010.

HAAS, P.; HOEHNE, L.; KUHN, D.. Revisão: avaliação dos efeitos do glifosato no ecossistema agrícola e sua toxicidade para a saúde humana. Revista Destaques Acadêmicos, v.10, n.4, p.82-90, 2018. DOI: http://dx.doi.org/10.22410/issn.21763070.v10i4a2018.2014

IQBAL, N.; KHALIQ, A.; CHEEMA, Z. A.. Weed control through allelopathic crop water extracts and S-metolachlor in cotton. Information Processing in Agriculture, v.7, n.1, p.165-172, 2019. DOI: https://doi.org/10.1016/j.inpa.2019.03.006

JABRAN, K.; MAHAJAN, G.; SARDANA, V.; CHAUHAN, B. S. Allelopathy for weed control in agricultural systems. Crop Protection, v.72, p.57-65, 2015. DOI: https://doi.org/10.1016/j.cropro.2015.03.004

KADIR, J.; CHARUDATTAN, R.. Dactylaria higginsii, a fungal bioherbicide agent for purple nutsedge (Cyperus rotundus). Biological Control, v.17, n.2, p.113-124, 2000. DOI: https://doi.org/10.1006/bcon.1999.0791

KRUSE, N. D.; TREZZI, M. M.. Herbicidas Inibidores Da Epsps: revisão De Literatura. Revista Brasileira de Herbicidas, v.1, n.2, p.139-146, 2000. DOI: https://doi.org/10.7824/rbh.v1i2.328 
MEYER, B. N.; FERRIGNI, N. R.; PUTNAM, J. E.. Brine shrimp: A convenient general bioassay for active plant constituents. Journal of Medical Plant Research, v.45, n.1, p.31-34, 1982.

PANNACCI, E.; LATTANZI, B.; TEI, F.. Non-chemical weed management strategies in minor crops: review. Crop Protection, v.96, p.44-58, 2017. DOI: https://doi.org/10.1016/j.cropro.2017.01.012

PAULUS, D.; PAULUS, E.; NAVA, G. A.; MOURA, C. A.. Crescimento, consumo hídrico e composição mineral de alface cultivada em hidroponia com águas salinas. Revista Ceres, v.59, n.1, p.110-117, 2012. DOI: https://doi.org/10.1590/S0034-737X2012000100016

PIRES, N. M.; OLIVEIRA, V. R.. Biologia e Manejo de Plantas Daninhas: alelopatia. Curitiba: Omnipax, v.2, p.95-124, 2011.

RIZZARDI, M. A.; FLECK, N. G.; VIDAL, R. A.; MEROTTO JR, A.; AGOSTINETTO, D.. Competição por recursos do solo entre ervas daninhas e culturas. Ciência Rural, v.31, n.4, p.707714, 2001. DOI: https://doi.org/10.1590/S010384782001000400026

SARTOR, L. R.; LOPES, L.; MARTIN, T. N.; ORTIZ, S.. Alelopatia de acículas de pínus na germinação e desenvolvimento de plântulas de milho, picão preto e alface. Bioscience Journal, v.31, n.2, p.470-480, 2015. DOI: https://doi.org/10.14393/BJ-v31n2a2015-18195

SERRA, A. P., MARCHETTI, M. E.; CANDIDO, A. C. S.; DIAS, A. C. R.; CHRISTOFFOLETI, P. J.. Influência do glifosato na eficiência nutricional do nitrogênio, manganês, ferro, cobre e zinco em soja resistente ao glifosato. Ciência Rural, v.41, n.1, p.77-84, 2011.

SVENSSON, B. M.; MATHIASSON, L.; MÅRTENSSON, L; BERGSTRÖM, S.. Artemia salina as test organism for assessment of acute toxicity of leachate water from landfills. Environmental Monitoring and Assessment, v.102, p.309321, 2005. DOI: https://doi.org/10.1007/s10661-005-6029-z
TEIXEIRA, D. E.; PAULA, R. L. G.; NAPOLITANO, H. B.. Legislação e Normatização para o Glifosato no Brasil. Revista Processos Químicos, v.13, n.25, p.105-116, 2019. DOI: https://doi.org/10.19142/rpq.v13i25.487

TORRETTA, V.; KATSOYIANNIS, I. A.; VIOTTI, P.; RADA, E. C.. Critical review of the effects of glyphosate exposure to the environment and humans through the food supply chain. Sustainability (Switzerland), v.10, n.4, p.1-20, 2018. DOI: https://doi.org/10.3390/su10040950

VAN BRUGGEN, A. H. C.; HE, M. M.; SHIN, K.; MAI, V.; JEONG, K. C.; FINCKH, M. R.; MORRIS, J. G.. Environmental and health effects of the herbicide glyphosate. Science of the Total Environment, v.616-617, p.255-268, 2018. DOI: https://doi.org/10.1016/j.scitotenv.2017.10.309

VIEIRA, L. R.; DA SILVA, E. R.; SOARES, G. L. G.; FIOR, C. S.; ETHUR, E. M.; HOEHNE, L.; FREITAS, E. M.. Phytotoxic effects of Morus nigra aqueous extract on germination and seedling growth of Lactuca sativa. Rodriguesia, v.69, n.4, p.21532161, 2018. DOI: https://doi.org/10.1590/21757860201869443

XU, J.; SMITH, S.; SMITH, G.; WANG, W.; LI, Y.. Glyphosate contamination in grains and foods: An overview. Food Control, v.106, p.1-8, 2019. DOI: https://doi.org/10.1016/i.foodcont.2019.106710

YAMADA, T.; CASTRO, P. R. C.. Efeitos do glifosato nas plantas: implicações fisiológicas e agronômicas. International Plant Nutrition Institute, n.119, p.1-32, 2007.

YANG, L.; LI, Y.; XJ, G.; MA, X.; YAN, Q.. Comparison of dry Ashing, wet Ashing and microwave digestion for determination of trace elements in Periostracum Serpentis and Periostracum cicadae by ICP-AES. Journal of the Chilean Chemical Society, v.58, n.3, p.1876-1879, 2013.

A CBPC - Companhia Brasileira de Produção Científica (CNPJ: 11.221.422/0001-03) detém os direitos materiais desta publicação. Os direitos referem-se à publicação do trabalho em qualquer parte do mundo, incluindo os direitos às renovações, expansões e disseminações da contribuição, bem como outros direitos subsidiários. Todos os trabalhos publicados eletronicamente poderão posteriormente ser publicados em coletâneas impressas sob coordenação da Sustenere Publishing, da Companhia Brasileira de Produção Científica e seus parceiros autorizados. Os (as) autores (as) preservam os direitos autorais, mas não têm permissão para a publicação da contribuição em outro meio, impresso ou digital, em português ou em tradução. 